\title{
Supramolecular Click Product Interactions Induce Dynamic Stiffening of Extracellular Matrix-Mimetic Hydrogels
}

Samantha E. Holt, Julio Arroyo, Emily Poux, Austen Fricks, Isabelle Agurcia, Marissa Heintschel, Amanda Rakoski, and Daniel L. Alge

\section{NMR Spectra}

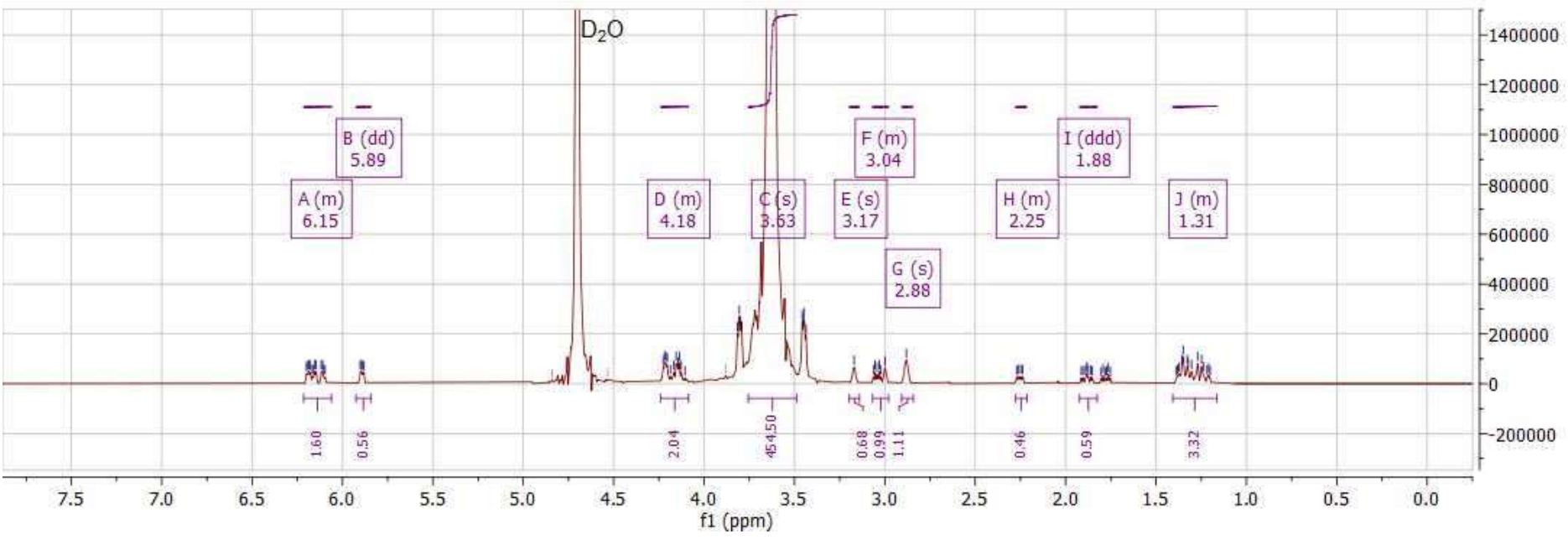

Figure S1. 40kDa 8-arm PEG-norbornene. ${ }^{1} \mathrm{H}$ NMR (400 MHz, $\left.\mathrm{D}_{2} \mathrm{O}\right) \delta 6.22-6.06(\mathrm{~m}, 2 \mathrm{H}), 5.89(\mathrm{dd}, J=5.7$, $2.8 \mathrm{~Hz}, 1 \mathrm{H}), 4.24-4.09(\mathrm{~m}, 2 \mathrm{H}), 3.63(\mathrm{~s}, 454 \mathrm{H}), 3.17(\mathrm{~s}, 1 \mathrm{H}), 3.07-2.98(\mathrm{~m}, 1 \mathrm{H}), 2.88(\mathrm{~s}, 1 \mathrm{H}), 2.28-2.21(\mathrm{~m}$, $0 \mathrm{H}), 1.88$ (ddd, $J=12.3,9.2,3.7 \mathrm{~Hz}, 1 \mathrm{H}), 1.78(\mathrm{dt}, J=11.8,4.1 \mathrm{~Hz}, 0 \mathrm{H}), 1.41-1.18(\mathrm{~m}, 3 \mathrm{H})$.

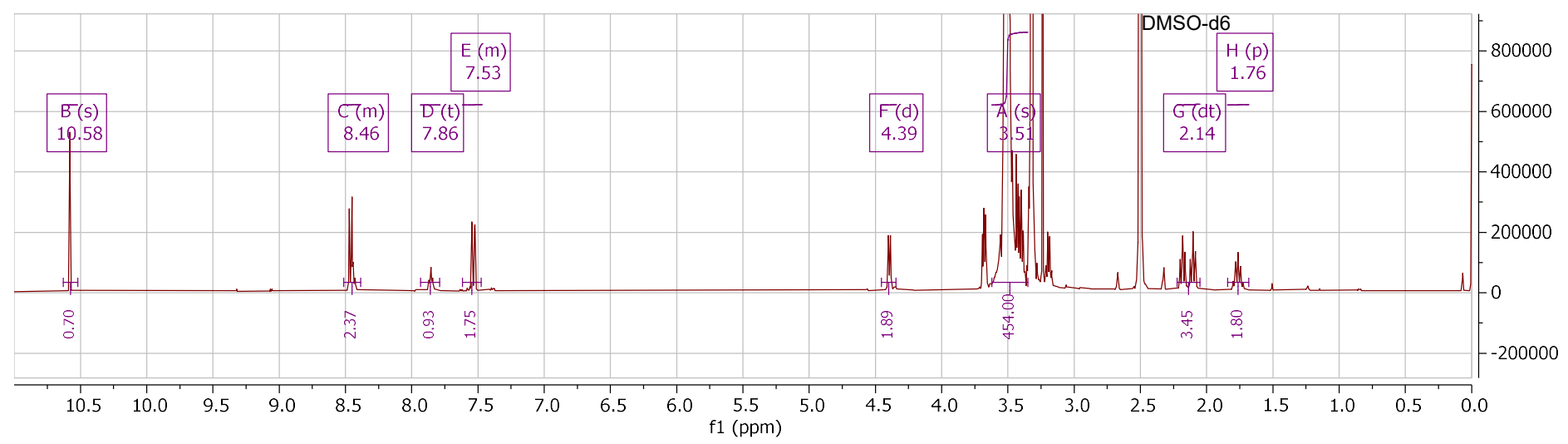

Figure S2. 5kDa methoxy-PEG-tetrazine. ${ }^{1} \mathrm{H}$ NMR indicated $90 \%$ end group functionalization with tetrazine. ${ }^{1} \mathrm{H}$ NMR $(400 \mathrm{MHz}, \mathrm{DMSO}) \delta 10.58(\mathrm{~s}, 1 \mathrm{H}), 8.50-8.40(\mathrm{~m}, 3 \mathrm{H}), 7.86(\mathrm{t}, J=5.6 \mathrm{~Hz}, 1 \mathrm{H}), 7.57-$ $7.50(\mathrm{~m}, 2 \mathrm{H}), 4.39(\mathrm{~d}, J=6.0 \mathrm{~Hz}, 2 \mathrm{H}), 3.51(\mathrm{~s}, \sim 454 \mathrm{H}), 2.14(\mathrm{dt}, J=31.1,7.5 \mathrm{~Hz}, 4 \mathrm{H}), 1.82-1.70(\mathrm{~m}, 2 \mathrm{H})$. 


\section{Supplemental Data}

A

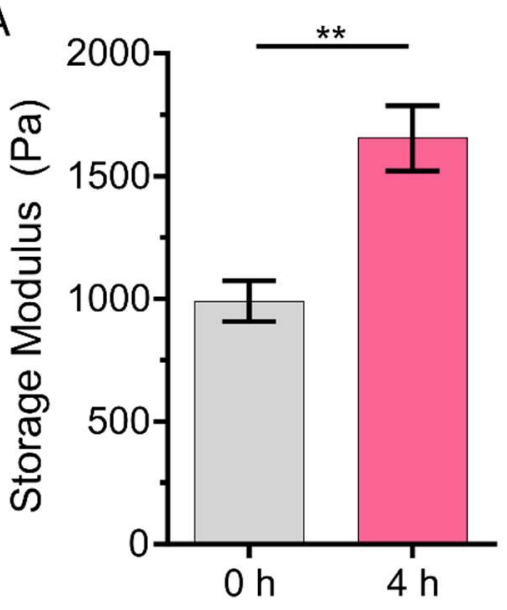

Time of $\mathrm{mPEG}-\mathrm{Tz}$ exposure

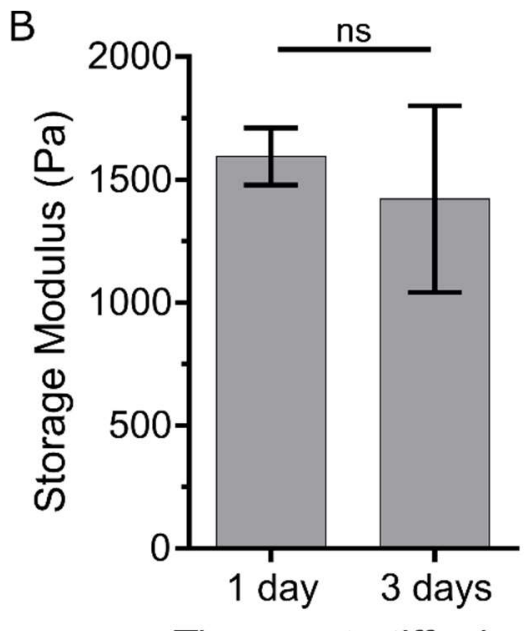

Time post-stiffening

Figure S3. Progressive stiffening in gels made in complete culture media. (A) $7.5 \mathrm{wt} \%$ PEG-Nb was combined with peptide crosslinker KCGPQ-W and cell adhesive peptide CGRGDS at a 1:2 thiol-ene ratio with $2 \mathrm{mM}$ LAP in complete culture media (DMEM $+10 \%$ serum $+1 \mathrm{X}$ penicillin/streptomycin). The shear storage modulus increased from $990.5 \pm 67 \mathrm{~Pa}$ to $1654 \pm 108 \mathrm{~Pa}(\mathrm{p}=0.0018, \mathrm{n}=3)$ after $4 \mathrm{~h}$ of treatment with $5.32 \mathrm{mM}$ mPEG-Tz in complete culture media under culture conditions $\left(37^{\circ} \mathrm{C}\right.$ and $\left.5 \% \mathrm{CO}_{2}\right)$. (B) The increased shear storage modulus persisted 1 and 3 days post-stiffening, though the modulus decreased slightly over time (1594 $\pm 95 \mathrm{~Pa}$ and $1421 \pm 309 \mathrm{~Pa}$, respectively, $\mathrm{p}=0.49$ ). 